\title{
Board Diversity or Tokenism: A Case for Social Inclusion and an Efficiency Model
}

\author{
Bello Lawal' ${ }^{1} \&$ Mohammed Nuhu² \\ ${ }^{1}$ Department of Business Management, Nile University of Nigeria, Abuja, Nigeria \\ ${ }^{2}$ Department of Business Management, BAZE University, Abuja, Nigeria \\ Correspondence: Bello Lawal, Nile University of Nigeria, Abuja, Nigeria
}

Received: November 20, 2020

Accepted: February 19, 2021

Available online: February 23, 2021

doi:10.11114/afa.v7i1.5174

URL: https://doi.org/10.11114/afa.v7i1.5174

\begin{abstract}
This exploratory paper examines the concept of diversity as a dynamic of board effectiveness. The study argues that diversity hardly works without putting in place systems and programmes that promote social inclusion, and, as such, research on board diversity must account for this element in building empirical frameworks and model specifications. The study finds that a great majority of previous studies have ignored this variable of significant importance and, in some instances, conflated it with diversity itself. This represents a material flaw that needs to be addressed. This paper offers guidance on how to measure and account for social inclusion and integration in board diversity research. Finally, a portfolio efficiency frontier model is proposed as a mechanism for differentiating between corporations with efficient board diversity and those that are tokenism based.
\end{abstract}

Keywords: board diversity, tokenism, social inclusion, corporations, efficiency frontier model

\section{Introduction}

Diversity is not a new topic when it comes to workplace dynamics, especially in developed economies. The concept originally focused on addressing social injustice and promoting equal opportunities for racial minorities and people of colour in the white-dominated workforce (Bursell \& Jansson, 2018; Jayne \& Dipboye, 2004; Rhode \& Packel, 2014). Diversity, then, was more of a social integration movement based on moral suasion, with corporations at liberty to design the manner and rate at which they achieved social inclusion without jeopardising shareholder value.

In contrast, the recent resurgence of the subject of diversity in the workplace can be attributed to two types of critical events: business scandals at highly respected corporations and anti-sexism actions. First, the collapse of global giants, such as Enron and WorldCom, has turned public attention to corporate boards and the effectiveness of directors in the discharge of their statutory obligations, which include executive monitoring, control, advising and oversight (Francis, Hasan, \& Wu, 2015; Singh, Terjesen, \& Vinnicombe, 2008). Reported cases of corporate scandals and the fallout from these events - loss of shareholders' funds, jobs and tax revenues - have demonstrated the far-reaching impact the decisions of boards of directors have on stakeholders' and societal wellbeing (Rhode \& Packel, 2014).

Second, the anti-sexism movement has equally fuelled discussions about diversity in the top corporate echelon. Unlike the traditional focus, current quests for diversity in the workplace are gender skewed, with the primary goal being more female involvement in strategic business decision making and corporate policy ratification (Farrell \& Hersch, 2005). So far, women advocacy movements have gained tremendous support from regulators and policymakers worldwide, with mounting pressure on corporations to move from what has been perceived to be an "old boys club" style of board structure to a heterogeneous formation with more female directors. Some jurisdictions have even gone beyond making simple code recommendations by imposing a gender quota system that has forced corporations to zone a certain proportion of directorship positions to women (Adams, Haan, Terjesen, \& Ees, 2015; Zhang, 2012).

Interestingly, though there are presumed benefits associated with the involvement of women in boardroom, concerns have been raised over forced involvement, including the adoption of binding quota systems and timelines for when corporations should diversify, which some have claimed may be counterproductive (Harjotoa, Laksmanab \& Yangc, 2018; Riordan, 2020; Sherbin \& Rashid, 2017). The proponents of this business rationale have argued that individual cognitive competence and resource dependency should take precedence over gender configuration (Bernilea, Bhagwatg 
\& Yonkerc, 2018; Campell \& Mínguez-Vera, 2008; Dalton \& Dalton, 2010; Pathan \& Faff, 2013). Therefore, the issue of gender parity is not the only variable of diversity under scrutiny; determining the appropriate number of experts with the required cognitive experience has also generated a great deal of debate in corporate governance literature.

However, notwithstanding the growing popularity of corporate scandals and the need to discuss gender and cognitive diversity in board dynamics and their intended benefits, there is little empirical validation of the relevance of these diversity dimensions in firm governance. Prior studies have reported equivocal results, which has created some doubts regarding the strategic importance of diversity to board effectiveness and overall corporate performance.

Here, it is argued that board diversity has merit and that the only missing piece in magnifying its merit empirically is called "inclusion". The majority of previous studies have either ignored this significant variable or, in some instances, have simply conflated it with diversity itself, which is inaccurate (Farndale, Biron, Briscoe, \& Raghuram, 2015; Fitzsimmons, 2012). This omission represents a material flaw in model specification and needs to be addressed. In this study, the validity of an isolationist approach to the study of board diversity as whole is challenged, particularly where cognitive and demographic elements are seen as standalone variables. It is argued that these variables are not in competition, but rather are integrated and complementary, and thus should not be separated when building a comprehensive definition of diversity for empirical purposes.

This paper is motivated by the need to offer additional research direction on the essence of diversity and the variables that may justify inclusive business practices and make a case for board diversity at the corporate level. Understanding the chronology of board diversity would help sharpen future research on what to watch for and where to look when exploring any correlations between board diversity and firm performance. Such description is vital, especially given the equivocality that has dominated prior studies, with many relying on non-cognitive variables, such as the main driver of board effectiveness, without recourse to the socioeconomic environment within which corporations operate (Lauring \& Villeseche, 2017; Rhode \& Packel, 2014). Using a portfolio efficiency frontier model, this paper adds insight into how over diversification through forced policy exposition can erode the benefits of board diversity in corporate governance.

The remaining sections of this paper are organised as follows: Section two is focused on the conceptual justification for board diversity and its associated benefits. Section three reviews key empirical studies and explores how far the documented evidence from prior research has supported (or disputed) the notion of board diversity and its relevance in firm governance. In section four, the paper highlights the bandwagon effects of rigid diversity policies and code recommendations on board effectiveness and makes a case for the implementation of social inclusion programmes and policies by corporations to help address tokenism syndrome, as well as for the adoption of a portfolio efficiency model in diversity research. Section five offers directions for future research and recommendations for policymakers.

\section{Rationale for Diversity in Board Composition}

The board of directors is the most widely studied aspect of corporate governance (Bernilea et al., 2018; Byron \& Post, 2016; Erhardt, Werbel, \& Shrader, 2003; Gray \& Nowland, 2017; Hillman, 2015; kang, Cheng, \& Gray, 2007; Nielsen $\&$ Huse, 2010). Directors perform numerous agency and resource dependence facilitations (e.g. monitoring and resource mobilisation) to mitigate the inherent risk of separation of ownership and control, which has caused shareholders billions of dollars in loss of investments and revenue. As a result, understanding bifurcate interplays of board dynamics is crucial in the selection and adoption of an internal governance mechanism. Over the years, experts and public commentators have turned their attention to the structure of the board and the characteristics that can endanger members' ability to discharge duties effectively (Kang et al., 2007). Issues of board size, independence, and separation of power have been well documented in the corporate governance literature. However, many have still argued that board composition should reflect the cosmopolitan nature of modern corporations and business operations. Van der Walt and Ingley (2003) argue that corporations face multifaceted challenges due to the growing complexity of businesses and environments, which, in turn, requires a diverse and talented workforce that can break through these external barriers. Having directors from diverse backgrounds promotes board oversight and hence the quality of deliberations at board meetings. For instance, Gul, Srinidhi \& Ng (2011) contend that diversity can help boards reduce information asymmetries. They found compelling empirical evidence that suggests diversity facilitates intelligence gathering, even in firms with poor earnings quality.

Interestingly, debates on corporate diversity have been anchored on two exciting dimensions: demographic and cognitive. The demographic dimension (e.g. age, race, and gender) has received more attention, with increased calls for women's participation in corporate decision making. The reason for this is that a significant portion of the directors prosecuted in the aftermath of high-profile corporate scandals were white males, and there was no female or racial minority involvement. Using the collapse of Enron as a case study, some critics have highlighted the lack of gender diversity as a crucial factor that led to the reported scandal. Because women are mostly risk-averse, Loukil and Yousif (2016) opine that their presence in the boardroom reduces corporate risk taking, unlike their male counterparts, who are often associated with high-risk investments. 
While some diversity experts have voiced the need to balance gender-related demands with cognitive rationales, advocates of these dimensions have continued to offer compelling justifications for the strategic importance of diversity in promoting board effectiveness. Harjotoa et al. (2018) argue that the degree of directors' heterogeneity affects a board's ability to carry out agency and resource dependency roles effectively. Advocates of board diversification have cited some presumed benefits associated with heterogeneous boards, including effective decision making, optimisation of corporate talent, and improved reputation. Slater, Weigand \& Zwirlein (2008) argue that deliberations in an efficiently diversified board are based on a broader perspective. Directors from different backgrounds create a pool of knowledge, capabilities and viewpoints that facilitate the attainment of corporate objectives. By tapping into the vast ideas that diversity of opinion creates, corporate boards can de-risk not only the likely passiveness of the board itself but also mitigate the inherent self-interest of CEOs and executive entrenchment. This represents the business rationale for diversity that has motivated more corporations to seek variety in human capital across the multicultural spectrum. When it comes resource dependency, a diversified board of directors provides a more efficient vehicle for linking corporations with the resources they need to facilitate value creation for shareholders (Van der Walt \& Ingley, 2003). Dalton and Dalton (2010) assert that external members bring to bear not only fresh ideas but also significant network connections for effective boundary spanning, which links corporations with required resources. Directors with social networks are very active in gathering intelligence and in helping corporations cushion the effects of adverse changes in market conditions (Rivas, 2012).

It is worth noting that regardless of the dimension, diversity in board membership represents a double-edged sword of presumed benefits and inherent costs for adopting firms. Members of diverse boards bring different and distinctive perspectives to the boardroom, which facilitates board oversight of corporate executives (Adams et al., 2015). The flip side to this, however, includes the fact that highly diversified boards often lack a sense of urgency and are more likely to spend more time arriving at strategic decisions due to cognitive and/or demographics-related conflicts. Therefore, while board diversity can be beneficial, it comes at a cost. Hence, corporations must evaluate these costs in light of accrued benefits to determine whether it is economical to pursue board diversity. Apart from the fundamental belief that some board diversities are tokenism based, issues such as role conflicts, stereotyping, split-factions and silo mentalities are some factors cited as likely to jeopardise board effectiveness and, by extension, erode the benefits of board diversity (Rhode \& Packel, 2014; Slater et al., 2008).

\section{Facts and Fiction of Board Diversity: Review of Empirical Evidence}

Despite the growing attention paid to board diversity across many jurisdictions, researchers have found it difficult to empirically validate the persuasive justifications put forward in the public domain and those cited from the policymakers' standpoint. In this section, the paper will review prior research and highlight the inconsistencies that have dominated empirical evidence, especially from studies that magnify the importance of diversity in firm governance. First, the study reviews findings from the demographic dimension of gender, which has received the most research interest. Female directors are presumed to be able to multitask, have great interpersonal skills and be meticulous, which mitigates potential CEO entrenchment (Fitzsimmons, 2012). Gender diversity has also been linked to specific task performance, such as sustainable supply chain responsibility (Benjamin, Mansi, \& Pandey, 2019); cost of debt (Pandey, Biswas, Ali, \& Mansi, 2029); audit quality (Lai, Srinidhi, Gul, \& Tsui, 2017); social performance (Byron \& Post, 2016); corporate reputation (Chen, Gramlich, \& Houser, 2019); shareholder activism (Marquardt \& Wiedman, 2016); corporate risk taking (Bernilea et al., 2018) and dividend pay-out (Byoun, Chang \& Kim, 2016). Yet, results from numerous studies on the impact of gender diversity on overall corporate financial and market value have been highly equivocal. Huctchinson, Mack, \& Plastow (2015), in a study of 500 listed Australian corporations, reported a positive correlation between gender diversity and financial performance in the face of reduced excessive risk taking. This finding was consistent with those reported in Vafaei, Ahmed, and Mather (2015), Ararat, Aksu \& Cetin (2015) and Erhardt et al. (2003). In contrast, in one of the most famous board demographic studies, Carter, D'Souza, Simkins, \& Simpson (2010) found no significant relationship between women and ethnic minority directors and corporate performance. As a matter of fact, the finding was distinctively consistent with results from countries with advanced gender parity support policies (Marinova, Plantenga \& Remery, 2016; Rose, 2007; Veltrop et al., 2015). For instance, Veltrop et al. (2015), in a study of 318 boards of Dutch Pension Fund firms, indicate that demographic diversity activates "fault lines" that impair cohesion among board members. Adams and Ferreira (2009) attribute this inverse relationship to the counterproductive impact of a mandatory gender quota system on corporations. Nielsen and Huse (2010) go a step further, finding no empirical evidence to suggest that the involvement of female directors provoked open debate or enhanced the quality of deliberation in boardrooms.

Cognitive diversity has not been spared from similar empirical inconsistencies. Bernilea et al. (2018) argue that a director's cognitive characteristics are the most relevant dimension, given that corporate survival is dependent on the delivery of a profitable performance. However, despite the business case for diversity, findings of studies that have investigated the relevance of cognitive characteristics, such as educational qualifications, expertise and tenure, have also lacked consistency. In a longitudinal study, Tan and Sen (2019) find a positive association between educational 
qualifications and directors' specialties and the performance of U.S. equity funds. Harjota et al. (2018) report similar findings in their study of 1,898 firms between 1998 and 2014. They also find that cognitively diversified boards provide better strategic oversight on investment risks. Their findings are interesting because they validate earlier research. For instance, Barroso-Castro, Villegas-Periñnan, \& Dominguez (2017), in a study of 200 big Spanish companies, find that directors' cognitive capabilities play a strategic role in their involvement in corporate board decision making. However, in a single empirical study, Kim and Lim (2010) find both a positive and a negative relationship between educational qualifications and firm value. While they report a positive association between academic specialisation and firm value, they find a negative connection between accounting qualifications and firm valuation, which is inconsistent, given that the accounting profession represents another field academic specialisation, just like others. Almondoz and Tilcsik (2016) study 1,300 community banks over a 17-year period and observe that banks with industry-expert-dominant directors are more likely to experience corporate failure due to high risk of cognitive entrenchment, overconfidence and task conflicts among members.

Regardless of which diversity dimensions are examined, a significant number of prior studies fail to reach a consensus. These inconsistencies have cast doubt on our understanding of diversity dynamics and their overall application in corporate governance. Hillman (2015) opines that as more questions related to the strategic relevance of board diversity are answered, new ones spring up at astronomical speed. In our review of prior studies, we observed a fundamental flaw in the translation of "diversity" as a concept and its application in the study of boards of directors. Unlike other board characteristics (such as size, composition and CEO duality), which are easily comprehensible and adaptable, diversity is a complex dynamic. Sherban and Rashid (2017), in their publication "Diversity doesn't stick without inclusion", offer an insightful explanation of the missing link and why studies on board diversity have failed to consistently demonstrate its presumed benefits, even among corporations that have yielded to societal and regulatory pressures. They argue that social inclusion (which defines the terms on which individuals in teams work together) is a strong moderator in the relationship between diversity and board effectiveness and performance. Riordan (2020) asserts that it is erroneous to assume that diversity presupposes inclusion. Unless outside directors who join corporate boards feel secure and accepted, their involvement amounts to little more than to window dressing and is less impactful. Simply adding female directors and those with relevant industry knowledge to corporate boards does not guarantee vigilance and effectiveness. This is because their contributions are limited by their level of participation and the extent to which their thoughts are valued and respected in board deliberations. If the concerned corporations diversified only in the interest of compliance with statutory requirements or adherence to societal demands as prudent business operators, their board diversification would not likely engender social inclusiveness between in-group and out-group board members. Therefore, delimiting the elements that adequately define social inclusion in research model specifications is crucial in valid empirical testing of the value of board diversity in corporate governance research.

In conclusion, our deduction from prior equivocal results is simple: Having diverse membership representation along demographic and cognitive dimensions may actually have benefits and underlying costs, with the former even likely to overweigh the latter; however, the weight distribution may vary significantly based on prevailing conditions and the general circumstances driving such configurations. Corporations must, thus, dig deep, beyond compliance with a quota system and the application of code recommendations, to gain a better understanding of what works best for individual entities, given their distinctive peculiarities, such as competitive position, market shares, industry classification, and macroeconomic realities. The adoption of forced diversification, such as a compulsory gender quota system and industry expertise, may be injurious to corporations (Riordan, 2020; Sherbin \& Rashid, 2017). Nevertheless, finding the optimal form of diversity will enable corporations to avoid bandwagon effects and tokenism syndrome. Tokenism and social inclusion are discussed in detail in the next section. Finally, a consistent difficulty found in the literature review is selecting which aspect of diversity (i.e. quality or quality) should take precedent is still a major blind post in discussions of board diversity. Most debates have focused on numeric diversity as contrastive to competence and negatively correlated with the size of the contribution directors are likely to make (Fairfax, 2005; Kim \& Lim, 2010). The calls for increased minority participation and gender parity are both numerically driven. However, beyond racial and gender delineation, competence and expertise are dynamic fundamentals when it comes to board workings and oversight. Therefore, the sticky point for corporations is determining the appropriate lead spindle between business rationale and societal expectations (Rhode \& Packel, 2014).

\section{Tokenism in Board Diversity: A Case for Social Inclusion and a Portfolio Efficiency Approach}

Without a doubt, diversity has received commendable attention in corporate governance, given the volume of research. From institutional and societal perspectives, pressure on corporations has been equally overwhelming. However, the preceding section highlighted how polarised the research remains with regards to inconsistency in findings. Some previous studies even suggest the need for an alternative theoretical framework for studying the relevance of board diversity in firm governance and corporate performance (Nielsen \& Huse, 2010). In this section, two new conceptual frameworks for empirical testing are proposed, and it is demonstrated how they can be used in board diversity research. 
The paper argues that resolving the pervasive research equivocality would require addressing the drawbacks of tokenism by advocating for social inclusion and the prevention of board overcrowding for effective oversight. Board diversity provides corporations with social capital due to the multiplicity of network connections that individuals from diverse backgrounds bring to bear, representing a vital source of resource dependency for corporations. Despite being an essential dynamic, the approach and extent to which boards of directors are diversified should be consistent with corporate goals (Slater et al., 2008) and firm-specific characteristics, such as ownership structure (Ben-Amar, Francoeur, Hafsi, \& Labelle, 2013); reputation and innovation (Miller \& Triana, 2009); role expectations (Nielsen \& Huse, 2010); industry classification (Farrell \& Hersch, 2005; Zhang, 2019); and degree of internationalisation (Rivas, 2012). So far, the introduction of diversity quota regulations has created misalignment and has done more harm than good in corporate board diversity, especially from an implementation standpoint. Basically, it is now a case of forcing horses to the stream but not being able to force them to drink. While there is increased compliance with diversity regulations in certain jurisdictions, the level of commitment demonstrated by corporations in making it work varies significantly (see Ciavarella, 2017; Farrell \& Hersch, 2005; Fitzsimmons, 2012; Ng \& Wyrick, 2011; Pathan \& Faff, 2013; Sila, Gonzalez, \& Hagendorff, 2016; Slater et al., 2008). Rhode and Packel (2014) argue that although significant progress has been made toward the entrenchment of diversity at the corporate board level, the lack of inclusion has impeded and deaccelerated the pace of progress.

As highlighted in the previous section, there is a clear distinction between diversity and inclusion. While diversity focuses on numeric attributes, such as the number of individuals from different demographic and cognitive configurations, inclusion is a process that ensures seamless integration and makes their presence really count (Henderson, 2014; Winters, 2014). To this end, while diversity can be legislated, inclusion is a soft skill attribute that is difficult to appraise, and thus perhaps more difficult to achieve than diversity. Structurally, corporations may externally adhere to board diversity regulations and yet refuse to make the necessary internal support changes that would create an enabling environment for success. This is an example of "tokenism", or diversity without inclusion. Tokenism represents the prospect of having a superficially diverse board in terms of demographic and cognitive parity without substantial internal drive to make it work as intended.

Diversity can be costly if adopted for tokenism. Slater et al. (2008) argue that the cosmetic adoption of diversity without due consideration of the inherent corporate culture is likely to hurt shareholders' earnings due to high costs. The cost of forced board diversity includes potential loss of cohesion due to lack of trust among members, sacrifice of competence for compliance, passive boards and groupthink syndrome due to overcrowding (Rhode \& Packel, 2014). Harjotoa et al. (2018) argue that directors with the required cognitive competencies are more likely to exhibit prejudice toward colleagues appointed on a quota-based system. Therefore, aside from the increased cost of governance, board performance can be impaired by the extent to which in-group and standing directors believe new directors merit the appointments that bring them onto the board. Should the in-group members have a sense that new entrant appointments are based purely on compliance with governance code or fulfilment of equality requirements, this will affect their openness and limit cohesiveness among board members. Lauring and Villeseche (2017), in their study of diversity and team attitude, affirm the above position, as they found a strong correlation between members' positive attitudes toward diversity and overall team performance. For new directors to function effectively in the boardroom, they need to be appropriately integrated and socially accepted by the in-group members.

It is interesting to note that the supposed benefits of diversity are basic presumptions that can only be realised with inclusion. What matters in diversity is not the variety of people but rather an enabling environment created to foster pragmatic collaboration and allow directors to showcase their inherent talent in helping corporations attain predetermined goals (Slater et al., 2008). Winter (2014) argues that diversity is just a "noun", but inclusion is the action word that makes the diversity really count. The effectiveness of board diversity as a corporate action is largely dependent upon whether it has enterprise-wide acceptability and commitment. For empirical testing, commitment to diversity can be measured using the Inclusion Equation (Winter, 2014). This model depicts key characteristics (macro and micro) of sustainable corporate inclusion. To explain and adapt the said model, we hypothesise, board diversity (i.e. demographic and cognitive) should be collectively recognised in both numeric and qualitative terms. Doing so would ensure that the study sample covered the characteristics of directors and the aspects of corporate commitment that are consistent with the exact definition of and principles behind board heterogeneity (i.e. Diversity + Inclusion). Following this recognition mechanism would automatically eliminate tokenism-diversified boards from the sample. This approach would also assist policymakers and corporate regulators in monitoring compliance and in factually differentiating between active and passive (tokenism-based) board diversity among corporations. The model in (i) illustrates our definition of board diversity for empirical testing. 


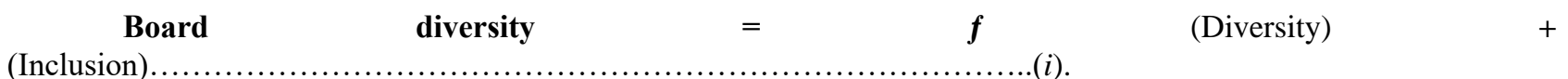

Figure 1. The model in (i) illustrates our definition of board diversity for empirical testing.

Diversity represents several demographic and cognitive dimensions of directors (including, but not limited to, age, race, gender, ethnicity, nationality, experience, education and expertise), in line with most definitions in previous studies (Theodorakopoulos \& Budhwar, 2015). After measuring diversity, the next step would be to check for inclusiveness, that is, whether, beyond diversity head counts, the affected directors are fully integrated into the corporations and boardrooms and have been provided an enabling atmosphere in which they can excel. Simulating by using an abridged Winter's Inclusion Equation, corporations would be scored across three visible dimension indices: shared values, structured inclusive systems, and cultural-cognitive competence. The existence of functional corporate shared values and whether those values support diversity and inclusion are captured in phrases used in the corporate vision and strategy statements. Identifying and measuring the shared values dimension would ascertain the degree to which diversity and inclusion culture are imbedded corporate-wide.

The second inclusion dimension measures corporate level of preparedness and maturity. Unlike diversity, corporate inclusiveness entails building a formal corporate structure and introducing corporate policies, procedures and practices that stimulate, support, recognise and respect diverse viewpoints. Corporations would thus be scored on whether they have formal systems and programmes in place that promote corporate inclusion. These might include dedicated diversity departments, on-boarding and buddy programmes for new entrants, and anti-discrimination and equal opportunity policy.

The third and final dimension measures the enterprise-wide level of cultural competence. Cultural-cognitive competence can be measured in two tiers. The first focuses on the level of leadership involvement and the tone at the top regarding driving inclusion. This would involve having diversity and inclusion as part of deliverables in corporate scorecards and executive performance contracts. The second part would measure corporate cultural awareness and cultural competency-building initiatives (such as training programmes and workshops), as well as whether corporations have shared values and inclusion network support groups where members share experiences and learn from each other (Slater et al., 2008).

Beyond social inclusion, another aspect of tokenism is the determination of the ideal level of board diversity and the prevention of board overcrowding. Societal pressure on corporations for increased demographic representation has both value-based and symbolic implications (Dalton \& Dalton, 2010; Farrell \& Hersch, 2005). If diversity enhances the social capital of the board, it is common sense that the addition of diverse directors would only but boost its ability to tap into larger networks in times of pressing need. However, it is also critical that corporations establish that peak point of diversity value, as any addition of diverse directors beyond this may reduce utility (Pathan \& Faff, 2013). This is why critics believe that legislating board diversity may engender overdiversification, or having too many heterogeneous directors than are rationally needed (Bernilea et al., 2018; Farrell \& Hersch, 2005; Gary \& Nowland, 2017). Zhang (2012) finds that board diversity is significantly linked to technical weakness, which reinforces the deduction that coercive diversity can be detrimental.

To address this innate weakness, we further hypothesise that the adoption of a "efficient frontier" portfolio model will help determine the most efficient level of board diversity to maintain a given corporation's inherent characteristics and business fundamentals. The efficient frontier model in portfolio theory provides a compelling methodology for understanding board diversity and a mechanism for achieving optimal diversity across demographic and cognitive dimensions. The theoretical argument of portfolio theory aligns with the key arguments researchers have put forward in testing the empirical validity of claims regarding board diversity. The model states that the "risk and reruns of an investment in a given security should not be assessed as standalone but rather evaluated in the context how its affect risk and return of the entire portfolio" (Markowitz, 1952). Applying this theoretical description to board dynamics, we theorise that the relationship between board diversity (i.e. demographic and cognitive) and performance should be assessed within the context of the social inclusion of the diversified members of the board.

Corporate boards represent a portfolio of directors as securities, and just as in any portfolio, efficiency is always dependent not only upon the number and quality of securities that make up the portfolio, but also the degree of sensitivity (i.e. inclusion) of each security within the given portfolio. Borrowing from portfolio theory, which sought to find optimal level of diversification along an "efficient frontier", we assume that the selection of directors on a corporate board should be based on multiple indicators that determine how efficiently they can fit into the board setting in terms of their ability to interact with other board members (i.e. social capital). In other words, more attention should be paid to the collectivism of board as a unit rather than having an excessively skewed focus on demographic and cognitive configurations, which only highlights individuals' qualities against those of the group (Farndale et al., 2015). 
Markowitz (1952) argues that having a diversified portfolio does not guarantee reduced volatility in the performance of securities therein. Consistently, board diversity alone, in terms of having different directors from varying demographic and cognitive denominations, is not sufficient to drive board performance; however, with an effective inclusion system, directors are more likely to work together and hence lessen the volatility associated with their diversity.

Researchers can construct a diversity verification index that seeks to achieve optimal diversification and determines corporations' position in the diversification efficiency frontier. The blend of indices used should cut across both demographic and cognitive indicators, with elements of social inclusion, as enumerated in the abridged inclusion equation discussed earlier in this section. An efficient frontier barometer would indicate whether a corporation is operating with efficient diversity (optimal and cost-effective) or a sub-optimally diversified board (tokenism based). For instance, corporations with board diversity scores on the upper level of the curve are assumed to be efficient, while those that fall outside the efficient frontier curve are regarded as inefficient in terms of board diversity because the cost of such diversity would most likely outweigh its probable benefits.

\section{Conclusion and Directions for Future Research}

Diversity in the corporate workforce is a valid paradigm for any prudent corporation operating in the modern and constantly evolving business environment. Drawing upon lessons from the corporate scandals of the last two decades, there is equally compelling evidence to support the growing call for diversity at top corporate levels, especially boards of directors. Diversity means that board members are from different backgrounds and are thus likely to think differently and offer diverse perspectives and ideas to aid in strategic corporate decision making. Therefore, membership diversity is critical in helping executives to unlock the opportunities that abound in the global marketplace through quality advisory and beneficial external networks.

However, this study differs in its recommended mechanism for achieving board diversity, specifically with regards to the adoption of quota systems, which are found to be impulsive, deficient and simplistic, giving the impression that diversity is a less complex process. Board diversity should be promoted in an integrated and flexible fashion and not necessarily through stringent codification and regulatory point-based systems. Researchers have struggled to clearly justify the need for board diversity, not because it is not beneficial, but due to the rigidity of the process in some jurisdictions (e.g. Spain, Italy, Norway and France), where corporations are not only forced to diversify their boards but are also given a predetermined ratio of how membership diversity should look. Apart from the inherent risk of CEO entrenchment, legislating board diversity promotes tokenism because corporations still reserve discretion to make it work through the deliberate institutionalisation of social inclusion and integration programmes (Bernilea et al., 2018; Slater et al., 2008). Prior studies after the implementation of a quota system still find it hard to empirically prove that such regulatory measures helped the corporations involved in terms of improved board and corporate performance. Those that find positive results attribute this to external environmental influences, mainly government incentives, rather than to diversity legislation.

We believe that diversity as a concept encapsulates two dynamics - "variety" and "inclusion" - but these dynamics have either been grossly misunderstood or wrongly applied in most previous corporate governance studies. Diversity without inclusion rarely works. While the former is a numerically based dimension that can easily be legislated, the latter represents soft skill mechanics that cannot be adequately legislated or enforced. Even though inclusion is a key element that enhances directors' task performance in the boardroom, most prior studies adopt a numeric definition, without accounting for inclusion. These parochial and paradoxical definitions, we believe, have fuelled the equivocality that has distorted empirical findings from both conceptual and methodological standpoints. For instance, the assumption of a linear relationship is a flawed model specification for diversity research simply because diversity can only endure effectively in an inclusive corporate setting.

In conclusion, this paper has offered two sets of recommendations, one focusing on regulatory and internal frameworks for board diversity, and the other offering a guide for future research. From a regulatory perspective, we recommend that directorship appointments should be devoid of coercion and corporations themselves should create an environment that promotes inclusiveness to aid board diversity, irrespective of whether it is demographic or cognitive based. Board members' mindset is equally vital in achieving inclusive diversity at the board level. In-group board members themselves need to embrace the new reality of heterogeneity, which would be characterised by having people from different backgrounds and walks of life all contributing to the achievement of common corporate goals.

As for future research, we recommend that researchers approach board diversity from a fresh and more pragmatic perspective. More precisely, this study calls for a significant paradigm shift on two aspects of diversity research. First, future studies need to move away from an excessive focus on demographics and toward a combination of both dimensions (i.e. demographic and cognitive). Second, in the data sample selection process, forced and legislated diversity boards must be recognised as outliers, with further investigation to determine the presence or lack of social inclusion and integration and the degree of cohesion among board members. Third, corporate governance research 
needs to evolve and be more adventurous, especially in cross-field applications of knowledge and in drawing up conceptual frameworks and models for research. For instance, this paper demonstrated how a corporate finance model (i.e. "efficiency frontier") can be used during the preliminary data testing stage to determine the efficiency level of directors' diversity in corporate board performance. This is the kind of originality that is likely to help resolve some of the unanswered puzzles of board dynamics in firm governance. Finally, we strongly encourage the investigative testing of the methodologies proposed in this paper to empirically validate their efficacy and suitability.

\section{References}

Adams R. B., Haan, J., Terjesen, S., \& Ees, H. (2015). Board diversity: Moving the field forward. Corporate Governance: An International Review, 2015, 23(2), 77-82.

Adams, R. B., \& Ferreira, D. (2009). Women in the boardroom and their impact on governance and performance. Journal of Financial Economics, 94, 291-309.

Almondoz, J., \& Tilcsik, A. (2016). When experts become liabilities: Domain experts on boards and organizational failure, Academy of Management Journal, 59(4), 1124-1149.

Ararat, M., Aksu, M., \& Cetin, A. T. (2015). How board diversity affects firm performance in Emerging Markets: Evidence on channels in controlled firms. Corporate Governance: An International Review, 23(2), 83-103.

Barroso-Castro, C., Villegas-Periñnan, M. M., \& Dominguez, M. (2017). Board members' contribution to strategy: The mediating role of board internal processes. European Research on Management and Business Economics, 23, 82-89.

Ben-Amar, W., Francoeur, C., Hafsi, T., \& Labelle, R. (2013). What Makes Better Boards? A Closer Look at Diversity and Ownership. British Journal of Management, 24, 85-101.

Benjamin, S., Mansi, M., \& Pandey, R. (2019). Board gender composition, board independence and sustainable supply chain responsibility. Accounting and Finance. https://doi.org/10.1111/acfi.12532

Bernilea, G., Bhagwatg, V., \& Yonkerc, S. (2018). Board Diversity, Firm Risk, and Corporate Policies. Journal of Financial Economics, 127(3), 588-612.

Bursell, M., \& Jansson, F. (2018). Diversity preferences among employees and ethnoracial workplace segregation. Social Science Research, 74, 62-76

Byoun, S., Chang, K., \& Kim, Y. S. (2016). Does Corporate Board Diversity Affect Corporate Payout Policy? Asia-Pacific Journal of Financial Studies, 45(1), 48-101.

Byron, K., \& Post, C. (2016). Women on Boards of Directors and Corporate Social Performance: A Meta-Analysis. Corporate Governance: An International Review, 24(4), 428-442.

Carter, D. A., D'Souza, F., Simkins, B. J., \& Simpson, W. G. (2010). The Gender and Ethnic Diversity of US Boards and Board Committees and Firm Financial Performance. Corporate Governance: An International Review, 18(5), 396-414.

Chen, L. H., Gramlich, J., \& Houser, K. A. (2019). The effects of board gender diversity on a firm's risk strategies. Accounting \& Finance, 59(2), 991-1031.

Ciavarella, A. (2017). Board Diversity \& Firm Performance Across Europe. CONSOB Working Papers No. 85.

Dalton, D. R., \& Dalton, C. M. (2010). Women and corporate boards of directors: The promise of increased, and substantive, participation in the post Sarbanes-Oxley era. Business Horizons, 53, 257-268.

Erhardt, N. L., Werbel, J. D., \& Shrader, C. B. (2003). Board of Director Diversity and Firm Financial Performance. Corporate Governance: An International Review, 11(2), 102-111.

Fairfax, L. M. (2005). The Bottom Line on Board Diversity: A Cost-Benefit Analysis of the Business Rationales for Diversity on Corporate Boards. Wisconsin Law Review, p. 795, 2005; University of Maryland Legal Studies Research Paper No. 2005-58. Available at SSRN: https://ssrn.com/abstract=835406.

Farndale. E., Biron, M., Briscoe, D. R., \& Raghuram, S. (2015). A global perspective on diversity and inclusion in work organisations. The International Journal of Human Resource Management, 26(6), 677-687.

Farrell, K. A., \& Hersch, P. L. (2005). Additions to corporate boards: the effect of gender. Journal of Corporate Finance, $11,85-106$.

Fitzsimmons, S. (2012). Women on boards of directors: Why skirts in seats aren't enough. Business Horizons, 55, 557-566.

Francis, B., Hasan, I., \& Wu, Q. (2015). Professors in the boardroom and their impact on corporate governance and firm 
performance. Financial Management, 44(3), 547-581.

Gray, S., \& Nowland, J. (2017). The diversity of expertise on corporate boards in Australia, Accounting and Finance, 57, 429-463.

Gul, A., Srinidhi, B., \& Ng, A. C. (2011). Does board gender diversity improve the informativeness of stock prices? Journal of Accounting and Economics, 51, 314-338.

Harjotoa, M. A., Laksmanab, I., \& Yangc, Y. (2018). Board diversity and corporate investment oversight. Journal of Business Research, 90, 40-47.

Henderson, E. (2014). The Chief Diversity Officer's View of the Diversity and Inclusion Journey at Weyerhaeuser. In B. M. Ferdman and B.R. Deane (Eds.), Diversity at work: The practice of inclusion (pp.431-450). San Francisco: Publisher: John Wiley \& Sons, Inc.

Hillman, A. J. (2015). Board Diversity: Beginning to Unpeel the Onion. Corporate Governance: An International Review, 23(2), 104-107.

Huctchinson, M., Mack, J., \& Plastow, K. (2015). Who selects the 'right' directors? An examination of the association between board selection, gender diversity and outcomes. Accounting and Finance, 55(4), 1071-1103.

Jayne, M. E. A., \& Dipboye, R. L. (2004). Leveraging diversity to improve business performance: Research findings and recommendations for organizations. Human Resource Management, 43(4), 409-424.

Kang, H., Cheng, M., \& Gray, S. J. (2007). Corporate Governance and Board Composition: diversity and independence of Australian boards. Corporate Governance: An International Review, 15(2), 194-207.

Kim, H., \& Lim, C. (2010). Diversity, outside directors and firm valuation: Korean evidence. Journal of Business Research, 63, 284-291.

Lai, K. M. Y., Srinidhi, B., Gul, F. A., \& Tsui, J. S. L. (2017). Board Gender Diversity, Auditor Fees, and Auditor Choice. Contemporary Accounting Research, 34(3), 1681-1714.

Lauring, J., \& Villeseche, F. (2017). Valuing Gender Diversity in Teams: the Importance of Attitudes and Degree of Gender Diversity. https://doi.org/10.5465/ambpp.2015.11881abstract

Loukil, N., \& Yousfi, O. (2016). Does gender diversity on corporate boards increase risk-taking? Canadian Journal of Administrative Sciences, 33, 66-81

Marinova, J., Plantenga, J., \& Remery, C. (2016). Gender diversity and firm performance: evidence from Dutch and Danish boardrooms. The International Journal of Human Resource Management, 27(15), 1777-1790.

Markowitz, H. (1952). Portfolio Selection. The Journal of Finance, 7(1), 77-91.

Marquardt, C., \& Wiedman, C. (2016). Can Shareholder Activism Improve Gender diversity on corporate boards? Corporate Governance: An International Review, 24(4), 443-461.

Miller, T., \& Triana, M. (2009). Demographic diversity in the boardroom: Mediators of the board diversity-firm performance relationship. Journal of Management Studies, 46(5), 755-786.

Ng. E. S. W., \& Wyrick, C. R. (2011). Motivational bases for managing diversity: A model of leadership commitment, Human Resource Management Review, 21, 368-376.

Nielsen, S., \& Huse, M. (2010). The contribution of women on boards of directors: Going beyond the surface. Corporate Governance: An International Review, 18(2), 136-148.

Pandey, R., Biswas, P. K., Ali, M. J., \& Mansi, M. (2019). Female directors on the board and cost of debt: evidence from Australia. Accounting and Finance. https://doi.org/10.1111/acfi.12521

Pathan, S., \& Faff, R. (2013). Does board structure in banks really affect their performance? Journal of Banking \& Finance, 37, 1573-1589.

Rhode, D., \& Packel, A. K. (2014). Diversity on Corporate Boards: How Much Difference Does Difference Make? Delaware Journal of Corporate Law, 39(2), 377-426.

Riordan, C. M. (2020). Diversity is useless without inclusivity. Retrieved from https://hbrascend.org/topics/diversity-is-useless-without-inclusivity/ (Accessed 24th March 2020)

Rivas, J. L. (2012). Diversity and internationalization: The case of boards and TMT's. International Business Review, $21,1-12$.

Rose, C. (2007). Does female board representation influence firm performance? The Danish evidence. Corporate Governance: An International Review, 15(2), 404-413. 
Sherbin, L., \& Rashid, R. (2017). Diversity doesn't stick without inclusion. Retrieved from https://hbr.org/2017/02/diversity-doesnt-stick-without-inclusion (Accessed 24th March 2020)

Sila, V., Gonzalez, A., \& Hagendorff, J. (2016). Women on board: Does boardroom gender diversity affect firm risk? Journal of Corporate Finance, 36, 26-53.

Singh, V., Terjesen, S., \& Vinnicombe, S. (2008). Newly appointed directors in the boardroom: How do women and men differ? European Management Journal, 26, 48-58.

Slater, S. F., Weigand, R. A., \& Zwirlein, T. J. (2008). The business case for commitment to diversity. Business Horizons, 51, 201-209.

Tan, E. K. M., \& Sen, A. (2019). Does educational diversity of managers matter for the performance of team-managed funds? Accounting \& Finance, 59(S1), 801-830.

Theodorakopoulos, N., \& Budhwar, P. (2015). Diversity and inclusion in different work settings: Emerging patterns, challenges, and research agenda. Human Resource Management, 54(2), 177-197.

Vafaei, A., Ahmed, K., \& Mather, P. (2015). Board Diversity and Financial Performance in the Top 500 Australian Firms. Australian Accounting Review, 25(4), 413-427.

Van der Walt, N., \& Ingley, C. (2003). Board Dynamics and the Influence of Professional Background, Gender and Ethnic Diversity of Directors. Corporate Governance: An International Review, 11(3), 174-185.

Veltrop, D. B., Hermes, N., Postma, T. J. B. M., \& de Haan, J. (2015). A Tale of Two Factions: Why and When Factional Demographic Faultlines Hurt Board Performance. Corporate Governance: An International Review, 23(2), 145-160.

Winters, M. F. (2014). From diversity to inclusion: An inclusion equation. In B. M. Ferdman and B.R. Deane (Eds.), Diversity at work: The practice of inclusion (pp.205-228). San Francisco: Publisher: John Wiley \& Sons, Inc.

Zhang, L. (2012). Board demographic diversity, independence, and corporate social performance, Corporate Governance: The international journal of business in society, 12(5), 686-700.

Zhang, L. (2019). An Institutional Approach to Gender Diversity and Firm Performance. Retrieved from https://doi.org/10.31235/osf.io/8792m

\section{Copyrights}

Copyright for this article is retained by the author(s), with first publication rights granted to the journal.

This is an open-access article distributed under the terms and conditions of the Creative Commons Attribution license which permits unrestricted use, distribution, and reproduction in any medium, provided the original work is properly cited. 